\title{
THE MOOR'S LAST SIGH: SPANISH-MOORISH EXOTICISM AND THE GENDER OF HISTORY IN BRITISH ROMANTIC POETRY
}

\author{
Diego Saglia \\ University of Parma
}

\begin{abstract}
Legends and tales of Islamic Granada were among the most frequently re-elaborated exotic subjects in British Romantic literature. A popular theme in the early decades of the nineteenth century, Spanish Orientalism attracted both famous writers such as Lord Byron, Joanna Baillie, Washington Irving, Felicia Hemans or Letitia Landon, and less familiar ones such as Lord Porchester, George Moir and Lady Dacre. This essay concentrates on one component of the myth of Granada which enjoyed great diffusion in Romantic-period literature, the tale of the Moor's Last Sigh and the tears shed by the last Muslim monarch on leaving his capital forever after the Christian conquest in 1492. The aim is to illustrate how, in migrating from its original context, this tale comes to signify and emblematize issues of gender and notions of history as progress specific to British culture. The poetic texts examined here employ the Spanish-Orientalist myth to elaborate ideas of masculinity and femininity, as well as reflections on power and its extinction, the fall of empires and the emergence of new states. Thus King Boabdil's tears were exotically popular also because they were removed from their original meaning and import, and refashioned into vehicles for ideological concerns proper to British Romantic-period culture.
\end{abstract}

"There are a few places scattered about this 'working-day world' which seem to be elevated above its dull prosaic level, and to be clothed with the magic lights and tints of poetry" -and one of these is Granada, the "charmed name" of which, "as if by fairy power, conjures up splendid scenes and pageants of the past" (Quarterly Review 1830: 55). Drawn from a piece on 
Washington Irving's A Chronicle of the Conquest of Granada (1829), these remarks designate the Andalusian city as one of the exotic locales par excellence in Romantic culture, a geographic, cultural and temporal elsewhere far removed from the mundane aspects of contemporary reality. The Quarterly reviewer thus confirms one of the most widely held notions of Romantic exoticism as escapism, a movement away from a "narrating" culture and towards a "narrated" place of difference capable of satisfying a deep-seated desire for the unattainable. Similar nineteenth-century observations have then fed into critical discourse on literary exoticism, providing the ground for definitions such as Henry Remak's recent characterization (1978: 54) of the exotic as "a phenomenon outside and beyond our normal cultural experience, not only one spatially remote, or culturally remote even if spatially fairly close, but potentially also one lying back [...] in time".

If, on the one hand, the example of Granada seems to bear out these definitions, on the other, its remoteness is bound up with issues that transhistorically reach out to the preoccupations of the bic et nunc of Romantic culture. In the piece on Irving's Conquest, these issues start to emerge as soon as the reviewer specifies that "The kingdom of Granada was the last strong hold of Moorish power, and the favourite abode of Moorish luxury" (Quarterly Review 1830: 55), thus combining intimations of the opulent vistas frequently suggested by the Arabian Nights with the epic subtext of the wars between Christians and Muslims in medieval Spain. In this fashion Granada's "spell upon the imagination" is also subsumed within referential categories with specific historical links: the end of the Middle Ages and the beginning of the modern era, the clash between East and West, the (im)possibility of transcultural, intercultural or even multicultural societies, the Romantic reflection on history and fiction, or the generic limits between epic and romance.

This essay seeks to chart the importance and pervasiveness of the "matter of Granada" in Romantic-period literature by following the (narrative and ideological) mutations of one central icon in this fictional repertoire -the tears shed by Boabdil, the last ruler of an Islamic kingdom in Spain, on leaving his capital and lands forever. Romantic views of Granada are indeed legible through Henry Remak's equation of the exotic and the remote, as well as through Roger Célestin's recent definition of exoticism as a "triangular trade", a tension between what he calls Home and Other and the uninterrupted transit between them. ${ }^{1}$ Exoticism inhabits the margin between two zones, a dialectic such as the one between East and West, or past and present,

1. In particular, Célestin (1996: 4) refers to a "tension between the gravitational pull of Home, the Same, the familiar, the dominant, and the individual subject's dissident desire for another place, an outside". 
recurrent in cultural constructions of Granada and re-elaborated by Romantic-period writers. However, the divide within exoticism that interests us here is more specifically that between fact and fiction, between the dreamy and romance-like features of the civilization of Granada and its "actual", historic relevance. The Quarterly reviewer's reference to the real and mythical traits of the Spanish Moorish city reveals that contemporary readers and critics were alert to this intersection between fact and fiction within the exotic. And this hybrid quality seems to indicate the possibility of a materialist interpretation of exoticism as the meeting point of Célestin's "triangular trade", an exchange loaded with ideological implications for the narrating culture.

The Quarterly reviewer of Irving's historical work highlights even more overtly the blurring of fact and fiction in the history of the last wars for the conquest of Granada, as may be appreciated from

[...] the striking contrast presented by the combatants of Oriental and European creeds, costumes, and manners; and in the hardy and hairbrained enterprises, the romantic adventures, the picturesque forages through mountain regions, the daring assaults and surprisals of cliff-built castles and cragged fortresses, which succeeded each other with a variety and brilliancy beyond the scope of mere invention. (Quarterly Review 1830: 56)

This evocation reads like a checklist of the lexicon of Romantic aesthetics (the picturesque and the sublime), and of its medievalist and orientalist inclinations. Yet, it also discloses a surprising erasure of the suspension of disbelief, limiting the aesthetic in order to highlight the non-fictional features of Granada: since the mythical city is also "beyond the scope of mere invention", it is extracted from more familiar views of exoticism and suddenly transported into the world of fact and reality. Being "one of those cases in which history rises superior to fiction" (Quarterly Review 1830: 56), the phantasms of Granada metamorphose into fact. Similarly, romance and epic coalesce in a combination of tales that, as in Irving's Conquest, may be chronologically verified. Thus the removal of Granada from a merely imaginative domain confirms the importance of its history and stories to the present of the narrating culture. Put otherwise, "The magic lights and tints of poetry" of Granada's tales (Quarterly Review 1830: 55) are also history and, as such, they represent an episode of exchange between "narrating" and "narrated" cultures exceeding the exotic as a merely escapist aesthetic.

This intersection of factual description and fictional representation is already apparent in the various forms of rediscovery and re-evaluation of the South of Spain within Romantic-period culture. On the basis of late eighteenthcentury pioneering work on the Spanish-Moorish antiquities by authors as diverse as Johann Gottfried Herder, Jean Pierre Claris de Florian, Bishop Percy 
and Henry Swinburne, the South of Spain establishes itself as one of the favourite exotic locales for European Romantic artists. ${ }^{2}$ Granada, in particular, becomes one of the crucial loci of this new geocultural horizon because of its status as a multiple borderland, the site of the intercultural transit proper to exotic representation. Indeed, Spain's exoticism in Romantic-period culture owes much to its inclusion of a cultural boundary within its own geographical boundary -the Islamic enclave contained within the natural divide of the Pyrenees- so that, until the late fifteenth century, Granada and Islam were another, even more exotic culture enclosed within an already quite peculiar Spain. ${ }^{3}$ And in late eighteenth-century European culture, the diffusion of the Spanish-Moorish material is directly linked to the tradition of interactions between Muslims and Christians in Spain, both cultures coexisting and contending for the same territory. The presence of different races, as well as multiple cultural, linguistic and religious traditions was, and still is, a recognized feature of Moorish Spain, although the kind of peaceful and tolerant convivencia sometimes praised by Romantic historians and fictional writers was in many cases more of an idealization than the actual state of things. ${ }^{4}$

Such intercultural contrasts and contacts between East and West in the constrictive geography of Granada inspired seventeenth-century dramatic texts such as William Congreve's The Mourning Bride (1697) and John Dryden's The Conquest of Granada (1670). But Spanish-Moorish exoticism emerged most forcefully between the 1770 s and the 1830s, starting from the impulse given by the translation of romances fronterizos and moriscos, usually drawn from Ginés Pérez de Hita's historical novel Las guerras civiles de Granada (1595, 1601). The first attempts at translating Spanish-Moorish ballads into English by

2. See Thomas Percy's Reliques of Ancient English Poetry (1765) which include two Spanish romances, or ballads, from Ginés Pérez de Hita's Guerras civiles de Granada (1595); Johann Herder's groundbreaking collection of Volkslieder (1778) which includes some romances by Luis de Góngora and a few from Guerras civiles; Florian's novel Gonzalve de Cordoue (1791) with its lengthy "Précis historique sur les maures d'Espagne"; and Henry Swinburne's authoritative and lavishly illustrated Travels through Spain, in the years 1775 and 1776 (1779).

3. As Henry Remak observes, "Spain [...] much more separate from the rest of Europe than France or Italy for many reasons including rugged geographical obstacles (the Pyrenees), her greater aridity, her Arab/African impregnation, her rigid brand of Catholicism, her more somber character, could well be -and was- felt to be exotic by the Romantics even in the immediately neighboring country of France" (Remak 1978: 55). On Romanticperiod forms of Spanish exoticism see also Hoffmann 1961, Alberich 1974-1975 and Saglia 2000 .

4. On convivencia in Moorish Spain as an unstable mixture of toleration and persecution, see Fletcher 1994; and on the frontier in Spanish-Moorish literature and its historical roots see Carrasco Urgoiti 1976. 
Samuel Johnson and Thomas Percy were soon followed by collections edited by Thomas Rodd, John Bowring and John Gibson Lockhart. ${ }^{5}$ Thomas Rodd also translated the first part of Pérez de Hita's Guerras civiles de Granada, published in 1803. As a result, the Romantic period saw an explosion of Spanish-Moorish fiction, including poems such as Felicia Hemans's The Abencerrage (1819), Letitia Landon's The Troubadour (1825), Eliza Norton's Alcon Malanzore (1815) and Lord Porchester's The Moor (1825); "closet drama" such as Barbarina Brand, Lady Dacre's tragedy Xarifa and her "romance dramatized" Gonzalvo of Cordoba (both published in 1821); prose works such as Washington Irving's Chronicle (1829) and The Alhambra (1832) or Edward Bulwer Lytton's Leila, or the Siege of Granada (1838); and spectacles such as Armand Vestris's ballet Gonzalve de Cordoue (1816) or the "grand opera" $A$ Night in Granada of 1842 (Saglia 2000: 254-69).

These texts variously capitalize on the nexus of fact and fiction, or the conflicts and contacts between East and West, implicit in the Spanish-Moorish material. Yet this crucial feature of Spanish Orientalism is perhaps no better encapsulated than in one recurrent narrative fragment and an episode which is emblematic of the last days of Islamic Granada: the story of the last Moorish king's sigh and tears on leaving his capital city and his mother's bitter reproach. This anecdote represents the culmination of the long wars between Catholics and Muslims, melodramatically sealing the severance of East from West in the Southern regions of the Iberian Peninsula. The striking scene of the last Moorish king's tears caught the Romantics' imagination, for it seemed to concentrate the net of related issues in the matter of Granada, as well as extracting the latter from atemporal suspension or elegiac evocation. Thanks to their recurrence in fiction and especially in poetry, the king's tears may be seen as a free-floating signifier in Romantic literary (and cultural) production, an ideologically charged image -an "ideologeme"- conveying a plurality of meanings hidden in the margin between fact and fiction, and an exotic narrative that evades reality and yet returns to it from a different perspective.

The king's tears and the dowager queen's reproach were recorded, although not expanded into a full-blown episode, by Pérez de Hita in the first part of his Guerras Civiles de Granada, a work grounded on the "historical" accounts in Esteban de Garibay's Compendio historial de todos los reinos de España (1571) and in Hernando del Pulgar's Crónica de los muy altos y esclarecidos reyes católicos don Fernando y doña Isabel de gloriosa memoria (1565 in Latin, 1567 in Castilian). A combination of history and romance, ballads and prose narrative, Pérez de Hita's book depicts the glittering court of

5. See Thomas Rodd's Ballads from the Civil Wars of Granada and the Twelve Peers of France (1801), John Gibson Lockhart's Ancient Spanish Ballads (1823) and John Bowring's Ancient Poetry and Romances of Spain (1824). 
the Alhambra and its sordid internecine fights, providing some of the essential plots in the Spanish-Moorish material: the killing of the Abencerrage clan ordered by king Boabdil, unwisely advised by the rival clan of the Zegris; the unjust charges of adultery levelled at his wife, once more insinuated by the Zegris; or the conquest of the citadel of Alhama by the Christian army. ${ }^{6}$ The king's tears are evoked in the conclusive section, and Hita drily relates: "Y ansí como el Moro Rey llegó a su casa, que era en el Alcaçava, començó a llorar lo que avía perdido. Al qual llanto le dixo su madre: 'Que pues no había sido para defendella como hombre, que hazía bien de llorar la como muger'”. ' Even so, as María Soledad Carrasco Urgoiti has perceptively remarked, the king's tears are more than an accessory theme emerging in the conclusion of the first section of Pérez de Hita's novel. In fact, they are a prelude to the pervasive sense of exile, elegy and nostalgia in the second section of the novel describing the ill-fated rebellion of the Moors against the Christian regime in the mountainous Alpujarra region:

La nota elegiaca de la nostalgia del desterrado, que en el primer libro aparece con el motivo del suspiro del moro, se proyecta en la historia de la rebelión sobre ciertos pasajes, en que el autor describe, por ejemplo, el sentimiento de soledad y melancolía que aqueja en ciertos momentos el reyecillo don Hernando de Valor - o Abenhumeya- [...] o alude al ansia por volver a sus casas de los moriscos que se han hecho fuertes en las montañas $[\ldots]^{8}$

Reproducing Pérez de Hita's brief remark, Thomas Rodd's English translation does not award any pre-eminence to the episode of the Moor's last sigh (Pérez de Hita 1803: 382). Yet a first re-elaboration and expansion of the plot had already been attempted by Jean Pierre Claris de Florian in his novel Gonzalve de Cordoue, published in French in 1791 and in English in 1792, prefaced by a lengthy "Précis historique sur les maures d'Espagne", a summary

6. On Pérez de Hita's novel and his personal involvement in issues of post-conquest Moorish society, see Carrasco Urgoiti 1976 and Carrasco Urgoiti 1982.

7. "And as soon as the Moorish King had returned to his home, which was in the Alcazaba, he started to weep over what he had lost. On seeeing him weep, his mother told him: 'That, since he had not been able to defend it like a man, he was right in crying for it like a woman"" (Pérez de Hita 1913-1915: I, 289, my translation).

8. "The elegiac tone of the exile's nostalgia, which in the first book appears in the motif of the Moor's sigh, is projected, in the tale of the rebellion, in certain passages where the author describes, for instance, the feeling of solitude and melancholy which at times besets the leader don Hernando de Valor -also called Abenhumeya- [...] or it emerges as an allusion to the anxious desire to return home on the part of the Moors who have been gathering strength in the mountains [...]" (Carrasco Urgoiti 1982: 278, my translation). 
of Moorish history often quoted as a source of information by later authors. The novel recounts the tale of cross-cultural love between Gonzalo Fernández de Córdoba (1453-1515), the Christian leader known as el gran capitán, and the Moorish princess Zulema. Here the Moorish king is a completely evil figure in contrast with Gonzalve's spotless heroism. Boabdil's defeat is thus wholly deserved and the inevitable reference to the Moor's last sigh is connoted as a well-earned punishment. Specifically, the sigh becomes tears, not to be confused with the positive, "sentimental" tears shed by other characters, and especially the hero himself. Florian (1836: I, 158) renders the "last sigh" as follows: "Mon fils, lui dit sa mère Aïxa, vous avez raison de pleurer comme une femme le trône que vous n'avez pas su défendre comme un homme". The words thus reported in the "Précis" are later reproduced in Book $\mathrm{X}$ of the novel with minor variations ("Oui, lui disoit-elle, tu dois pleurer comme une femme, puisque tu n'as pas su comme un homme défendre le trône de tes aïeux"). ${ }^{10}$ Thanks to this factual and fictional reelaboration, Florian's version of the episode, influential on both sides of the Channel, was quoted in non-fictional works such as Alexandre de Laborde's encyclopaedic $A$ View of Spain (1809), as well as in primarily imaginative texts such as Lord Porchester's poem The Moor ${ }^{11}$

In British Romantic literature, the most sustained poetic transposition of Pérez de Hita's Granadine narrative materials is Felicia Hemans's The Abencerrage, a long narrative poem in three cantos and in heroic couplets published in the collection Tales, and Historic Scenes, in Verse (1819). ${ }^{12}$ Granada in Hemans's complex text emerges as a decadent civilization on the eve of the Christian conquest, ruled by the ineffectual and effete last king Abdallah (a variant of "Boabdil"), and riven by internal dissensions between

9. "My son, his mother Aixa told him, you are right in crying like a woman over the throne that you were incapable of defending like a man" (my translation). On the importance of the larmoyant element in this novel, see Wiegman 1971: 52-3 and, on the sentimental-political value of tears in Chateubriand's Le dernier Abencérage, 68-9.

10. "Yes, she told him, you must cry like a woman, for you have been incapable of defending like a man the throne of your ancestors" (my translation).

11. Florian's "Précis" is quoted in the prose introduction and notes to Lord Porchester's poem The Moor (1825), while Alexandre de Laborde's Voyage pittoresque et historique de l'Espagne (1806-1820), the most monumental and complete survey of contemporary Spain written during the Romantic period, frequently invokes Florian as an authority in its wide- account of the Alhambra in volume II, as in the description of the Court of Lions (Laborde 1809: II, 104). Laborde's work in the original French is reproduced in the Revue Hispanique vol. 63 (1925).

12. While in the first edition of Hemans's collection The Abencerrage appears in the middle of the book, in the second edition (1824) it becomes the opening text. Remigio Ugo Pane lists it as an adaptation of Pérez de Hita's Guerras civiles (Pane 1944: 162). 
clans and tribes, especially the valorous Abencerrages and the treacherous Zegris. Against this background Hemans sets the ill-fated love-story of Hamet and Zayda belonging, in Romeo and Juliet fashion, to the opposed factions, and whose lives are caught up in the chaos of war and the fall of the last Islamic kingdom in Western Europe. Through this intersection of imperial history and intimate stories, Hemans proposes a reflection on the contending claims of heroism and domesticity, publicness and privacy, and male and female codes of conduct, themes which are also crucial in the rest of her poetic production (Mellor 1993: 123-143; Wolfson 1994: 128-135).

In this articulated reworking of Pérez de Hita's materials, the episode of the Moor's last sigh and tears appears as a fragment lost in the variety of themes and motifs interwoven by Hemans in her polemical reinscription of the romance, chivalric ideology and masculine views of history. Yet the fragment of the Moorish king's tears can also be linked to the wider thematic field of gender. And, from the point of view of masculinity, the poem records a gallery of examples ranging from the chivalric valour usually attributed to the Moors ("the chivalrous, the bold", I.26, Hemans 2000: 2), the cowardice of the plotting Zegris as opposed to the heroism of the Abencerrages, Hamet's belief in patriarchal and patrilinear links, and finally king Abdallah's fearfulness ("Degenerate fear [Granada's] wavering monarch guides", II.398, Hemans 2000: 112). The latter's allegiance to a code of virile honour is constantly undermined, as Hemans records only the negative aspects of his rule without hinting at the difficult political situation surrounding a figure that Hita called el rey chico ("the little king"). Indeed, Abdallah's "degenerate" fear signifies the decline of the Moorish civilization and power, while his figure is the embodiment of this specific fall of an empire. Also, as the last of his race and the representative of its inexorable decline, the monarch embodies a wellknown Romantic topos:

Last of a line whose regal spirit flown

Hath to her offspring but bequeath'd a throne

Without one generous thought, or feeling high,

To teach his soul how kings should live and die. (II.399-402, Hemans 2000: 112)

In these lines, a prelude to the later episode of the king's tears, Abdallah emblematizes the inglorious end of the history of Moorish Granada. Giving further dramatic enhancement to this characterization in the scene of the tears and the Queen Mother's taunts, Hemans stakes out a confrontation between a virile nation and an effeminate, spent civilization, a contrast which is made even more striking by the fact that Abdallah's sighs follow directly on the Catholic monarchs' first visit to the Alhambra after the fall of the enemy city. And central to Hemans's re-telling of the episode of the tears is the Dowager 
Queen, who addresses and interrogates her degenerate son before voicing her final reproach:

\author{
-Weep'st thou Abdallah?- Thou dost well to weep, \\ O feeble heart! o'er all thou couldst not keep! \\ Well do a woman's tears befit the eye \\ Of him who knew not, as a man, to die. (III.171-174, Hemans 2000: 121)
}

As in the lines in canto II quoted above (399-402), acting as a prelude to the unmanly tears, once more the stress is on virility symbolized by the act of dying an honourable death as confirmed by the repetition of the rhyme on "die". In this fashion the narrator and the queen make explicit the correspondence between male heroism and heroic death, transforming what may seem a marginal episode into the final emblematic judgment on the failure of a masculine set of values and a representative male figure. The scene is then given further resonance as Hemans also inserts it in the notes to her poem, making it relevant to both levels of the text, prose and verse, fact and fiction. ${ }^{13}$

In particular, the Queen Mother's words reveal that Hemans's version of the Moor's last sigh shifts from the traditional mother/son confrontation to an inversion of masculinity and femininity. The story therefore becomes productive as the site of a conflict of gender: Boabdil's tears and the queen's harsh words blur the line between masculine and feminine, the woman assuming authority and appropriating the "royal" voice, whereas man is diminished into powerlessness and silence. Seen in this light, the Abdallah/Aixa confrontation is a historic version, firmly located in the public sphere of empire, of the other confrontation deployed by Hemans through the mode of the romance and Hamet and Zayda's star-crossed love-story which similarly destabilize and redistribute notions of feminine and masculine. Here the Zegri heroine is abandoned by her lover, who decides to desert to the Christian side after his clan has been slaughtered by order of the king. After Hamet's departure, she follows the male members of her family and joins the armed Moorish resistance against the invaders. The hero, by contrast, becomes weaker and weaker, his masculinity gradually lessened from an initial embracing of patrilinear heroics to the position of a traitor to his country. If

13. "Abo Abdeli, upon leaving Granada after its conquest by Ferdinand and Isabella, stopped on the hill of Padul to take alast look of his city and palace. Overcome by the sight, he burst into tears, and was thus reproached by his mother, the Sultaness Ayxa: 'Thou dost well to weep, like a woman, over the loss of that kingdom which thou knewest not how to defend and die for, like a man'" (Hemans 2000: 134). Hemans does not provide a source for this quotation. 
Zayda first hails him in the idiom of virile heroism ("Oh! be thou still the highsoul'd and the brave, / To whom my first and fondest vows I gave", I.361-362, Hemans 2000: 99), later she resolutely rejects him as a deserter and a traitor: "Leader of hostile bands! away, away!" (II.250, Hemans 2000: 109). Eventually, the poem's inversion of male heroism into destructive vengeance and hatred climaxes when Hamet is sent on a mission to quash the Moorish resistance in the mountains and thus also to slay his Zegri beloved and her family. In this final section, although Zayda and Hamet are reunited in a conclusion that proves love's strength against all odds, her immediate reaction is to reject the hero and dismiss the ideal of romantic love: "Was it for this I loved thee? -Thou hast taught / My soul all grief, all bitterness of thought!" (III.461-462, Hemans 2000: 128).

In the historic and public level of Abdallah and Aixa, as well as in the fictional and private sphere of Hamet and Zayda, the feminine raises its voice to condemn a code of masculine values that is ultimately bankrupt and only capable of bringing death and destruction. Indeed, as suggested by Nanora Sweet (2001: 192), in The Abencerrage Hemans shows her ability to turn "historical romance" into "surprisingly unsentimental history". The romance form -implicitly "feminine" or feminized through its insistence on a chivalric love ethos- is made to convey a tale that, by addressing history, reduces and qualifies its own allegiance to the sentimental. Sentimentalism in its most unmotivated, powerless and gratuitously mawkish form is now located in the masculine dimension of the king's tears. Present in three different versions, the latter episode must then be recognized as one of the crucial ideological foc $i$ in the text. Through its repetition Hemans condenses the central issues in the poem: the interdependence of private and public, the conflict between masculine and feminine, and the gendering of history. Visibly caught up in the exotic tension between fact and fiction, the tears become the outward, dramatized translation of the preoccupations animating Hemans's metrical tale.

The episode is similarly woven into a discourse of gender relations in the first canto of Lord Byron's Don Juan, published in the same year as Hemans's narrative and by the same publisher, John Murray of Albermarle Street. Hemans was an admirer of Byron's verse and The Abencerrage visibly re-elaborates the situations and figurative materials of metrical tales such as The Giaour and The Bride of Abydos; yet her poetic style was unaffected by Byron's more recent and experimental mode displayed in poems such as Beppo and Don Juan. Albeit very different, their two texts of 1819 form an unusual dialogue, evidencing gender-inflected uses of the intercultural fragment of the episode of the Moor's last sigh. In particular, in the first canto of Byron's Don Juan, the scene of Boabdil's tears emerges in connection with the figure of the Sevillian Donna Julia, who seduces the young hero and starts him on a career of reckless and unlucky love affairs. The Spanish-Moorish 
legend is part of the polyphony of cultures, languages and traditions that criss-cross in the opening canto of Byron's unfinished poem; ${ }^{14}$ and the Moor's tears belong to a curious imbrication of cultural-geographic and gendered issues present in the description of Donna Julia and inscribed in her physical appearance and genealogy:

The darkness of her oriental eye

Accorded with her Moorish origin;

(Her blood was not all Spanish, by the by;

In Spain, you know, this is a sort of sin.)

When proud Grenada fell, and, forced to fly,

Boabdil wept, of Donna Julia's kin

Some went to Africa, some staid in Spain,

Her great great grandmamma chose to remain (I.56, Byron 1980-1993: V, 26).

A good instance of Don Juan's interweaving of public and private and its modifications of conventional points of view, this stanza closes in on the female body, whilst simultaneously expanding it into a repository of the history of civilizations, intercontinental migrations and the definition of discrete national and racial zones. Julia's eye is both a fragment of her body, the part that stands for the whole seductive ensemble, and the lens through which the history of Spanish-Moorish Granada is telescoped. Julia's oriental eye synecdochically compresses her physical presence and opens up the unlimited vistas of the Spanish-Moorish narrative of the fall of Granada. The legend is inscribed in her oriental beauty and femininity, which thus recapitulate the subjection of the (Spanish) East to the (Spanish) West, the recovered unity of Spain at the end of the Reconquista, yet also its inevitably contaminated racial and religious "purity". Through Byron's daring perspectival shift, the private, intimate story of the body becomes a map of the development of the history of Spain. By the end of the stanza, however, the field of vision returns to focus on the personal and private: here the fall of Granada and Boabdil's quickly dispatched tears function as an appendix to Julia's family and personal development. Once again, the feminine prevails over the masculine, as history and civilization are here "monumentalized" through an attractive, oriental-Western female body (Saglia 1996: 132-133).

Of course, through the Spanish-Moorish fragment Byron introduces the kind of orientalized femininity that plays such a large part in the deployment of Juan's sexual adventures along the Mediterranean. Moreover, by giving

14. On Byron's poem as made up of a multiplicity of voices and viewpoints enacting a "carnivalized" pluralization of reality, see Martin 1993. 
pre-eminence to the feminine over the masculine and subsuming the male into the female, the episode of the king's tears is in tune with the gender reversals of the first canto of Don Juan where Donna Julia's figure is permanently "on top"; additionally, it points to Juan's sexual passivity and its temporary climax in cantos V-VI, where first he is a sexual object imperiously desired by the Sultana Gulbeyaz, and then an odalisque in the Sultan's harem. Boabdil's passivity and feminization may therefore be read as a mise en abyme of Juan's sexual passivity and the poem's continuous reversals of the sexual power game between men and women.

Yet the relevance of the episode of the Moor's tears goes beyond the mere introductory function of pre-scribing later erosions of sexual identity in Byron's poem. Importantly, the tears also record the miscegenation of cultures, the impossibility of separating Europe and Africa, Christianity and Islam or East and West because of their genetic interconnections. In this sense Boabdil's tears function as a factual-fictional embodiment of the principles of polyphony and hybridity underpinning Byron's writing in Don Juan. The Spanish narrative fragment becomes enmeshed in a textuality founded on hyperbole, inversion and subversion, which reinterprets the episode by taking the process of feminization present in the original to one possible (comic) extreme. As with Hemans's version, then, the tears emblematize a form of historical disempowerment; and if The Abencerrage staged a male loss of authority and a female seizing of the regal voice, in Byron's lines the episode serves to dismantle ideas of racial purity and wholeness, notions of linear historical development and unmixed national-cultural trajectories. By way of the Moor's tears Byron encodes a historical-cultural reflection into the comedic development of the first canto of Don Juan that visibly inverts the meaning of the original episode and its emblematic function as a demarcation of the re-established divide between East and West. Exposing the myth-making within images of the boundary, the Spanish-Moorish material is here a contentious fragment that undermines the self-evidence of the ideology of intactness. ${ }^{15}$

Byron's and Hemans's treatments multiply the meanings of the Moor's last sigh and tears by capitalizing on their intermediate status between fact and fiction. By contrast, elegiac and dream-like, that is more conventionally exotic, uses of this figurative material re-surface in a later cluster of texts published around 1824 and 1825 , as the legend began to migrate freely from narrative poems to shorter treatments in the literary journals and magazines. Thus, in 1824, Henry Colburn's New Monthly Magazine, edited by Thomas Campbell,

15. On the cultural geography of the boundary and the frontier see Rumley and Minghi 1991. 
published a series of poems on Granadine themes among which was "The Last Look of Granada" by "G. M.", the Scottish poet George Moir. In this elaborate descriptive poem of 88 lines, in Claude Lorrain fashion the author inserts the tale of Boabdil's last sigh within an overwhelming description of the urban and natural landscape of the Moorish city. ${ }^{16}$ As a discursive correlative of Romantic visual renditions of Granada by the likes of Louis Albert Bacler d'Albe, James Cavanah Murphy, Richard Ford, David Roberts or Owen Jones, ${ }^{17}$ Moir's language rehearses well-known views of the city and its surroundings as a distillation of the sublime and the picturesque. The long, opening descriptive section evokes familiar themes such as decadence and the passing away of empires in the context of the romanticized landscape of Granada bathed in the light of sunset:

O! the evening sun goes sweetly down

On the old Alhambra walls

At the close of day, when the sunbeams stray

Through the lone and silent halls (1-4, Moir 1824: 83)

The elegiac tone evoked by the setting sun, the impression of generalized decay and the melancholy intimations of the fall of empires are further

16. George Moir (1800-1870), advocate and author, was a prolific translator from the German (Schiller's Piccolomini and Wallenstein, 1827, and the 'History of the Thirty Years' War', 1828) and the Spanish. He was also a regular contributor to Blackwood's Magazine. The $D N B$ indicates that in 1824, the year when his poem on Granada was published in the New Monthly Magazine, Moir was engaged on a critical article on the ancient ballad poetry of Spain. Vol. 10 (1824) of the New Monthly also contains the following poems on the theme of Granada: "The Fall of Granada, or the Massacre of the Abencerrages" (pp. 66-7), "Queen Isabel's Wish" (pp. 245-6) where a note to the title states that "The original of much of this will be found in Gines Pérez" (p. 246), "Alfaïma's Lament" (p. 296), with another note to the title: "See the history of Boabdil, the last Moorish King of Granada", and "The Surprise of Alhama" by "L." (p. 316).

17. General Bacler d'Albe took part in the Napoleonic campaign in the Iberian Peninsula and produced a vast amount of picturesque views, later published as lithographs (Dérozier 1970). The architect James Cavanah Murphy had travelled to Spain in 1802 to study the Moorish style and in 1815 published the lavishly illustrated The Arabian Antiquities of Spain (Raquejo 1986). Richard Ford, author of a celebrated Handbook for Travellers in Spain (1845), stayed in Spain between 1830 and 1833 and, for a period, was quartered in the Alhambra. During his stay in the Peninsula, he produced over 500 drawings of Spanish monuments. The Scotsman David Roberts took a first trip to the South of Spain in 1832-1833 and his drawings, later published as illustrations to Thomas Roscoe's The Tourist in Spain (1835) and as Picturesque Sketches in Spain (1837), were among his most popular publications (Symmons 1996). Owen Jones arrived in Granada in 1834 and began drawing and sketching the royal palace in all its aspects, publishing the results in his monumental Plans, Elevations, Sections and Details of the Alhambra (1842-45) (Sweetman 1988: 119-30). 
developed in the sections that follow as an introduction to the culminating episode of the Moor's last farewell to his city and kingdom, extended over more than thirty lines. Here Boabdil's gaze first takes in the whole expanse of the fortified town, its countryside and encircling mountain-range ("the Paradise of Spain", 64, Moir 1824: 84), then salutes them for the last time:

"Farewell! ye towers, and streams and bowers,

A last farewell," he said:-

Outspake his queenly mother then

As she raised her stately head:

"Tis well thy part -the coward heart

Should end as it began,

And he may weep, that could not keep

His kingdom like a man." (81-88, Moir 1824: 84)

The queen's words -slightly veined with irony in the third-person of "he may"- conclude Moir's poem. And the final exchange between mother and son once more reproduces a shift between masculine and feminine, so that, whereas the woman is "stately" and "queenly", cowardly Boabdil fades away, unnamed, his voice silenced by the more powerful utterance of his mother. Mostly a re-elaboration of well-known exotic materials, Moir's poem confirms the distribution of masculinity and femininity, power and disempowerment, set out by the Spanish version of the tale, as well as testifying to the freedom with which the episode of the Moor's tears was appropriated and elaborated in early nineteenth-century British literature.

The following year saw the publication of a more transformative treatment of the tale in Henry Herbert, Lord Porchester's poem The Moor (1825) where, as in Hemans's Abencerrage and in classic orientalist fashion, Boabdil features as an evil despotic ruler swayed by his mother and insanely jealous of his wife. Porchester's poem is an ambitious and copiously annotated metrical tale in which the young aristocratic author even attempts a reconstruction of the cultural, socio-political and economic conditions of the kingdom of Granada at the close of the fifteenth century. Like Byron before him, Porchester had travelled across Spain in 1822, a young lord on a Grand Tour meant as part of his political education and future parliamentary career. On this occasion he had been received by King Ferdinand VII, and later Porchester returned to the Peninsula several times, becoming an expert on Spanish affairs whilst making a name for himself both in the House of Commons and the Lords during the campaign leading to the Reform Bill of $1832 .{ }^{18}$

18. On Porchester see, besides the Dictionary of National Bibliography, Robertson 1975 : 206-209. 
Drawing on the author's archival as well as first-hand knowledge of Spain, The Moor offers itself as a romance and a historically reliable reconstruction of an episode in Spanish history -the events leading up to the battle of Lucena (1483) - shot through with reflections on politics and economics. At eighty pages, the prose preface is a detailed disquisition on the Moorish nation, aimed at equipping the reader with a wealth of historical, economic and sociopolitical notions. The poem, by contrast, is built around a fictional Moor of the Almoradi tribe, Hassan, and his diplomatic journey to a council in Castile with Spanish leaders who eventually refuse to sign a peace treaty with Granada, a dismissal which precipitates the battle of Lucena and the final phase in the Christian conquest of the Islamic territories. Throughout the poem Boabdil is presented as an incapable ruler, the embodiment of a slothful, luxurious and tyrannical Eastern power, a stereotypical representation of oriental despotism figured through the king's decadent hedonism:

Apart, in high alcove, the Monarch lay, Reposing from the beams of sultry day;

The spangled garb of Tunis round him roll'd, And o'er his head the canopy of gold:

Here figured china scatter'd incense roundThere Persia's purple carpet deck'd the ground; Her silks fell fair o'er gilded balustrade, Where fount of fretted alabaster play'd (Porchester 1825: 183)

Reclining under a canopy, surrounded by the accumulated luxuries of the East, Boabdil is both a semi-divine icon and the symbol of a decidedly Asiatic (and backward) political-economic system in which the ruler is the site of all power and the point of convergence of all the revenues and treasures of the state. Boabdil's presentation as the hub of a system of oriental absolutism makes him a belated representative of that type of Asiatic despotism demonized by the eighteenth-century philosophes and later analyzed by Karl Marx as a specific political-economic dimension under the rubric of the "Asiatic mode of production" (O'Leary 1989: 17-18; Grosrichard 1979). Yet, even as he revises the historical relevance of Boabdil's role, Porchester does not forget the fictional side of the matter of Granada and thus also proleptically writes the king's tears into his poem from the very beginning:

[...] thrill'd with anguish as he look'd his last,

[He] Wept o'er the realms he ruled with sovereign pride,

Yet lived an exile when the monarch died,

His high-soul'd mother sternly bade him know

It ill became him, with a woman's woe

To mourn o'er lost Granada's living grave-

The throne he knew not like a King to save. (Porchester 1825: 6) 
At first glance these lines simply seem to replicate the familiar tale inseparable from any account of the final days of the last Muslim kingdom in Spain. But, on closer inspection, the text betrays a resistance to showing the king's tears as a debasing spectacle of masculinity "gone wrong". Differently from the poems already examined, the impact of the Queen Mother's reproach is lessened by the avoidance of direct speech and by turning the loss of Granada into the more circumscribed, less apocalyptic loss of a throne, a formulation that harks back to Florian's Gonsalve de Cordoue, a text amply quoted in Porchester's preface and footnotes. Furthermore, the king's "woman's woe" is ill-becoming, for it clashes with the code of restrained virility proper to chivalry and held up both in the preface and in the representation of the hero Hassan, as well as in the extensive evocations of tournaments, duels and courtly celebrations in the verse tale. In other words, Porchester's text stresses that Boabdil is not man enough, having infringed the chivalric code shared by Christians and Muslims alike, rather than defining him as an effeminate figure or a man indulging in feminine behaviour.

In addition, just like Hemans before him, Porchester duplicates the episode of the tears and asserts its emblematic centrality by transcribing an unattributed prose version of the tale in a note where the Queen Mother's reproach is given even more relevance: "My Son, it ill becomes you to lament an empire that you had not the manhood to defend'" (Porchester 1825: 283). It is interesting that, in so far as we consider Pérez de Hita's version an "original" (at least in the environment of British Romantic-period culture), Porchester's footnote is closer to the Spanish account, addressing Boabdil as a "man", whereas the poetic text defines him as "King". This shift away from the original text seems to indicate that Porchester's rewriting moves from an undermining of masculinity (relegated to the footnote) to an undermining of Boabdil's royal position and authority (given full visibility in the poetic text). Therefore what he has lost is a throne, and his "woman's woe" is indecorous and inappropriate especially because it clashes with an ideal of stoic male heroism. In The Moor the weeping king features as an anti-model, a figure manipulated and reworked in order to suit the text's agenda of celebrating manly, warlike values and diplomatic skills.

By contrast, a treatment of the Moor's tears which again wrests power away from an enfeebled male hand to bestow it on to a powerful female figure is Letitia Landon's "The Sultana's Remonstrance", a lyric in her bestselling volume The Troubadour, published in the same year as Porchester's less successful poem. The long metrical tale which gives the title to the whole volume already contains an elaboration of the Spanish-Moorish theme as the hero, a Provençal knight-troubadour, joins a crusade against the Moors of Spain, is made prisoner and manages to escape from his dungeon with the help of a fascinating Moorish damsel who falls in love with him. But, if the 
main poem in the volume explores the territories of the Catholic-Islamic frontier, "The Sultana's Remonstrance" is set after the disappearance of that boundary, investigating the awareness of the vanished borderline and its consequences. Landon's version of the Moor's tears once more centres on the female figure of the queen. Startlingly, as if the whole background to the episode needed no introduction, her text begins with the scornful words addressed by Aixa to her son:

\author{
It suits thee well to weep, \\ As thou look'st on the fair land, \\ Whose sceptre thou hast held \\ With less than woman's hand. (Landon 1990: 266)
}

One aspect to emerge from this iambic quatrain is that "woman" is not used contemptuously to imply a negative comparison with female weakness. Rather, the mother's voice is stronger than the king's and power is vested in her. Being "less than woman's", Boabdil's hand is consequently deprived of any true authority. He is no longer accused of displaying a woman's woe or woman's tears, nor is he accused of not being man enough. More radically, Landon's re-elaboration defines Boabdil's behaviour as inferior to the female model, annulling the negative connotations in the term "woman" as handed down by the original Spanish version of the Moor's last sigh and still present, for instance, in Hemans's "woman's tears".

The rest of Landon's lyric then expands and details Boabdil's loss of power and authority, his being paradoxically neither man nor woman, by applying the redistribution of gender to the entire geography of Granada. The latter is typically presented as a place of gardens and halls, protected by high defensive walls (Saglia 1997), and the queen points it out to her degenerate son for the last time:

\footnotetext{
On yon bright city gaze,

With its white and marble halls, The glory of its lofty towers,

The strength of its proud walls.

And look to yonder palace,

With its garden of the rose,

With its groves and silver fountains,

Fit for a king's repose. (Landon 1990: 266)
}

The Alhambra and the city's palaces are built on a precise distribution and balance of masculine (the defensive walls) and feminine (the halls and gardens). Granada thus appears here, and in numerous other representations 
of its architectural marvels, as a place of gendered tensions closely related to the present of the narrating culture rather than merely confined to the timelessness of the exotic locale. In her remonstrance, the Sultana makes clear that, as the king of a heroic male population, Boabdil should have belonged to the former dimension: "Their fathers died for thy fathers,- / They would have died for thee" (Landon 1990: 266). However, the king has pledged allegiance neither to the masculine nor to the feminine values of the city. As a result, following the Christian conquest, even the male population of Granada is defeated: the city is now inhabited by "aged men" and "young knights [...] with folded arms" (Landon 1990: 266). Through this destabilization of the city's gendered architecture, and in the ensuing vacuum of male power, authority is now appropriated by the queen who personifies of the voice of history. As it rewrites the gender relations in the legend of the Moor's last sigh, Landon's ballad-style lyric stages feminine resistance to masculine values and Granada becomes a dream of civilization lost by male ineptitude.

Written and published between 1819 and 1825, the texts examined in this essay constitute a localized corpus evidencing a variety of uses and interpretations of the legend of the Moor's sigh in the British literary environment of the late 1810s and the early 1820s. Also after 1825, however, the popularity of the Granadine theme continued unabated. François-Rene de Chateaubriand's Le dernier Abencérage, published in 1826, presented the episode of the Moor's tears in one of its opening sequences and was also inspired by the French translation of Pérez de Hita's Guerras civiles by Alexandre Marie Sané (1807). ${ }^{19}$ It was translated into English anonymously as Aben Hamet, the Last of the Abencerages in 1826, an extract of which was published in Rudolph Ackermann's Repository of Arts (vol. 8, nr 44, 1 August 1826). A second translation appeared in 1835 , this time by Isabel Hill, author of the English version of Madame de Staël's Corinne (1807) for which Letitia Landon provided translations of the odes into English. In 1829 the Reverend George Hughes published The Last Sigh of the Moor: A Poem, and in 1833 John Graham of Wadham College, Oxford, published his Granada: A Prize Poem. The year 1835 saw the publication of Thomas Roscoe's descriptive narrative The Tourist in Spain: Granada, with illustrations by David Roberts, and intended as part of Jennings's Landscape Annual series. In 1850 Roscoe published his poem The Last of the Abencerrages, or the Fall of Granada. A year later, after the end of the Great Exhibition, the Crystal Palace was

19. The French translation was also introduced by a literary and historical account of Moorish Spain: Histoire chevalresque des Maures de Grenade trad. de l'espagnol de Ginés Pérez de Hita et précedée de quelques réflexions sur les Musulmans d'Espagne, avec des notes historiques et littéraires par Allexandre] M[arie] Sané, 2 vols (Paris: Clérioux jeune et H. Nicolle, 1809). 
removed from Hyde Park to Sydenham, in South London, and was transformed into a series of architectural courts: here Owen Jones converted one of these spaces into an "Alhambra Court" that reproduced miniature versions of the Court of Lions, the Hall of the Kings and the Hall of the Abencerrages (Crinson 1996: 63-65). In all of these recreations of the exotic elsewhere of Granada, the sigh and tears of the last Moorish king are either overtly represented or part of a background of nostalgic tales of faded architectural grandeur, lost splendour and doomed heroism.

The multiplicity of meanings of Boabdil's tears in Romantic and Victorian Britain is rooted in the polysemy of the Moor's last sigh in the Spanishlanguage tradition. In Spanish Renaissance culture, when the defeat of Granada and the expulsion of the Moors were still relatively recent events, the episode was endowed with both elegiac and triumphant overtones. The Moor's sigh was a sentimentalizing episode in the context of "romantic" views of late medieval Granada as an opulent, refined and chivalrous court, similar in many respects to contemporary Christian courtly environments. The heroic representatives of the Muslim aristocracy were thus turned into "sentimental" Moors, and indeed the first section of Pérez de Hita's novel grants special relevance to these characters in accordance with what María Soledad Carrasco Urgoiti (1976: 121) has defined as an underlying concern that "the assimilation of Moorish gentry by Christian society be effected" in late sixteenth-century Spain. ${ }^{20}$ This appreciative view of Moorish Granada became particularly widespread after its defeat, when the Islamic enemy was no longer a threat and in keeping with the chivalric tendency to sympathize with a vanquished yet valorous foe. But in Spanish literature the image of the Moor's last sigh also functioned as a scornful judgment on a defeated civilization and an emblematic moment sealing the closure of one's "natural" national boundaries.

In its migration from its original contexts to the literary discourse of British Romantic culture, the Moor's last sigh acquires new meanings in relation to debates on gender, the preoccupation with history as progress, and the passing of humanity and its institutions, specific to the receiving culture. The texts examined in this essay play with ideas of masculine and feminine, reordering the boundary between "man" and "woman", as well as with notions of power and its loss, the fall of empires or the emergence of new states. Boabdil's tears thus appear to be at least doubly productive: first, because of the gender inversions they set in train, secondly, because of the politicalhistorical reflections they subsume.

20. On the figure of the sentimental Moor in Spanish literature, and its reappearance in Spanish Romanticism, see Adams 1968. 
Boabdil takes centre stage as a fascinating figure, located half-way between fact and fiction, the chronicling of the fall of a kingdom, on the one hand, and a variety of symbolical significations, on the other. Taken together, the re-elaborations examined in this essay transform the last Moorish king of Granada into a palimpsest where identities shift between extremes, fixed points of reference oscillate, and seemingly clear-cut concepts momentarily turn into their opposites. As free-floating signifiers imported into the network of British Romantic writing, Boabdil and his tears are a superimposition of narratives and issues available for authors to manipulate and reinvent. Boabdil may feature as the patriarchal oriental despot, embodying the excess of virility proper to clichéd Eastern sultans, yet also as an emasculated figure because of his tears. He is the effete Asiatic, whose effeminacy and weakness are finally borne out by his weeping. And he represents the shift from absolute power to a powerlessness condensed in the signifier of the tears which transcribes the last trace of an extinct dynasty and a lost empire. The Moor's sigh and tears are what may be called a "productive embarrassment" for British Romantic writers, an infringement of a code of masculine stoicism which is also a redistribution of the sentimentalist topos of tears. Eighteenth-century tears had been a primary indicator of a refined sensibility, sympathy and superior humanity, the weeping of both men and women amply recorded in literary texts as a physical manifestation of their inner virtues. Boabdil's tears, by contrast, are extracted from this mythologizing of sentiment and redeployed as individual weakness, on the one hand, and as a sign of imperial-cultural decline and catastrophe, on the other. Accordingly the king's tears belong in a figuration of failed masculinity and male-dominated history, oriental effeminacy, the melancholy of the last of the race or even, as in Byron, an icon of intercultural fertilization and impurity. ${ }^{21}$

More generally, therefore, Boabdil's tears reveal that, while Romanticperiod treatments of the exotic maintain, and capitalize on cultural difference, they simultaneously tend to assimilate and employ it in figurations of, and reflections on, the narrating culture. The exotic is confirmed as a dimension exceeding familiar cultural experience through spatio-temporal distance. But, once this "unmarked", abstract status of the exotic becomes part of the appropriating and translating culture, the other and its figures bear directly on the materials, issues and ideas of familiar cultural experience. The line between Home and Other, to return to Roger Célestin's terminology, is blurred as the "different" becomes part of the discourses with which "sameness" narrates itself to itself. And these discourses are enmeshed in the present dimension of the narrating culture to such an extent that the exotic no longer

21. On the continuing productivity of this episode, see Cantor 1997. 
functions as a suspended signifier, but rather becomes an "ideologeme", a site of contention where crucial issues are staged, played out and (occasionally) redefined.

One of the sections in Washington Irving's The Alhambra (1832) is a compendium of Boabdil-related legends entitled "Mementoes of Boabdil". The episode of the tears is not forgotten and, once more, the text rehearses Queen Aixa's well-known rebuke: "You do well [...] to weep as a woman over that you could not defend as a man". Her words are then glossed by the authoritative voice of the narrator-compiler, a veritable guide through the mysteries of the Islamic remains of Southern Spain, who adds that this is "a speech savouring more of the pride of the princess than the tenderness of the mother" (Irving 1925: 169). ${ }^{22}$ The power struggle in this minimal exchange is brought to the reader's attention by an intrusive comment which makes it clear that the narrative fragment conceals more than just a curious piece of exotic lore or the melodramatic epilogue to an epic fight in the annals of East-West confrontations. Indeed, overtones of tension are present in all the reelaborations seen here, but now the fragment no longer indicates an intercultural or military tension tout court: its meanings have shifted within the sphere of the receiving tradition. In this new shape it encapsulates conflicts proper to British Romantic tradition and its discourses, continuing to produce meanings and stimulate interpretations well into the Victorian age and beyond.

\section{REFERENCES}

Adams, N. B. 1968. "The Duke of Rivas and the Gallant Moor". Revista Hispánica Moderna 34: 103-107.

Alberich, J. 1974-1975. "La imagen de España en la Inglaterra del ochocientos". Filología Moderna 52-53: 95-116.

Byron, G. G. 1980-1993. The Complete Poetical Works. Ed. J. J. McGann. 7 vols. Oxford: Clarendon Press.

Cantor, P. A. 1997. "Tales of the Alhambra: Rushdie's Use of Spanish History in The Moor's Last Sigh". Studies in the Novel 29: 323-341.

Carrasco Urgoiti, M. S. 1976. The Moorish Novel: El Abencerraje and Pérez de Hita. Boston: Twayne.

22. Irving also recorded the episode of Boabdil's tears in his Chronicle of the Conquest of Granada of 1829: "Boabdil burst into tears. His mother, the intrepid Ayxa, was indignant at his weakness: "You do well', said she, 'to weep like a woman, for what you failed to defend like a man!"' (Irving 1909: 341). On the Chronicle, see Wiegman 1971: 73-96. 
Carrasco Urgoiti, M. S. 1982. "Ginés Pérez de Hita frente al problema morisco". Actas del cuarto congreso internacional de hispanistas (Salamanca, 1971). Ed. E. de Bustos Tovar. 2 vols. Salamanca: Universidad de Salamanca. I, 269-281.

Célestin, R. 1996. From Cannibals to Radicals: Figures and Limits of Exoticism. Minneapolis, London: University of Minnesota Press.

Crinson, M. 1996. Empire Building: Orientalism and Victorian Architecture. London and New York: Routledge.

Dérozier, C. 1970. La Campagne d'Espagne: Lithographies de Bacler d'Albe et Langlois. 2 vols. Paris: Les Belles Lettres.

Fletcher, R. 1994. Moorish Spain. London: Phoenix.

Florian, J. P. C. de 1836. Gonzalve de Cordoue, ou Grenade reconquise. 2 vols. Paris: A. Pougin.

Grosrichard, A. 1979. Structure du sérail: la fiction du despotisme asiatique dand l'Occident classique. Paris: Seuil.

Hemans, F. 2000. Selected Poems, Letters, Reception Materials. Ed. Susan Wolfson. Princeton and Oxford: Princeton University Press.

Hoffmann, L.F. 1961. Romantique Espagne: L'image de l'Espagne en France entre 1800 et 1850. Princeton: Publications du département de langues romanes de l'Université de Princeton; Paris: Presses Universitaires de France.

Irving, W. 1909. The Works of Washington Irving. Vol. V: Conquest of Granada and Spain. London: George Bell.

Irving, W. 1925. The Alhambra. Introd. by E. R. Pennell. London: Macmillan.

Laborde, A. de 1809. A View of Spain... translated from the French of Alexander de Laborde. 5 vols. London: Longman, Hurst, Rees, and Orme.

Landon, L. E. 1990. Poetical Works of Letitia Elizabeth Landon "L.E.L.". Ed. F. J. Sypher. Delmar: Scholars' Facsimiles \& Reprints.

Martin, P. 1993. "Reading Don Juan with Bakhtin". Don Juan. Ed. Nigel Wood. Buckingham: Open University Press. 90-121.

Mellor, A. K. 1993. Romanticism and Gender. New York and London: Routledge.

G. M. [Moir, G.] 1824. "The Last Look of Granada". The New Monthly Magazine 10: 83-84.

O'Leary, B. 1989. The Asiatic Mode of Production: Oriental Despotism, Historical Materialism and Indian History. Oxford: Blackwell.

Pane, R. U. 1944. English Translations from the Spanish, 1484-1943. New Brunswick: Rutgers University Press.

Pérez de Hita, G. 1803. The Civil Wars of Granada; and the History of the Factions of the Zegries and Abencerrages. Trans. Thomas Rodd. London: Ostell. 
Pérez de Hita, G. 1913-1915. Las guerras civiles de Granada. Ed. P. Blanchard-Demouge, 2 vols. Madrid: Imprenta de E. Bailly-Baillière. Porchester, H. H., Lord 1825. The Moor. London: Charles Knight. Quarterly Review 1830 (May) 43: 55-80.

Raquejo, T. 1986. "The 'Arab Cathedrals': Moorish Architecture as Seen by British Travellers". The Burlington Magazine 128: 555-563.

Remak, H. H.H. 1978. "Exoticism in Romanticism". Comparative Literature Studies 15: 53-65.

Robertson, I. 1975. Los curiosos impertinentes: Viajeros ingleses por España 1760-1855. Madrid: Editora Nacional.

Rumley D. and Minghi J. V. eds. 1991. The Geography of Border Landscapes. London and New York: Routledge.

Saglia, D. 1996. Byron and Spain: Itinerary in the Writing of Place. Lampeter, Lewiston: Edwin Mellen Press.

Saglia, D. 1997. "The Exotic Politics of the Domestic: The Alhambra as Symbolic Place in British Romantic Poetry". Comparative Literature Studies 34: 197-225.

Saglia, D. 2000. Poetic Castles in Spain: British Romanticism and Figurations of Iberia. Amsterdam, Atlanta: Rodopi.

Sweet, N. 2001. "Gender and Modernity in The Abencerrage: Hemans, Rushdie, and the 'Moor's Last Sigh". Felicia Hemans: Reimagining Poetry in the Nineteenth Century. Eds. N. Sweet and J. Melnyk. Basingstoke and New York: Palgrave. 181-195.

Sweetman, J. 1988. The Oriental Obsession. Cambridge: Cambridge University Press.

Symmons, S. 1996. "Castles in Spain: Romantic Tourists and Literary Landscapes". Romantic Geographies. Ed. C. Smethurst. Glasgow: University of Glasgow French and German Publications. 137-147.

Wiegman, N. A. 1971. Ginés Pérez de Hita y la novela romántica. Madrid: Plaza Mayor.

Wolfson, S. 1994. “Domestic Affections' and 'the Spear of Minerva': Felicia Hemans and the Dilemma of Gender". Re-Visioning Romanticism. British Women Writers, 1776-1837. Eds. C. S. Wilson and J. Haefner. Philadelphia: University of Pennsylvania Press. 128135 . 